\title{
Uji Validitas Neutrophil Gelatinase Associated Lipocalin sebagai Penanda Diagnosis Gangguan Ginjal Akut pada Sepsis
}

\author{
Hidayat, ${ }^{1}$ Ida Parwati, ${ }^{1}$ Rubin Surachno Gondodiputro, ${ }^{2}$ Coriejati Rita ${ }^{1}$ \\ ${ }^{1}$ Laboratorium Patologi Klinik Rumah Sakit Dr. H. Abdul Moeloek Lampung , ${ }^{2}$ Departemen Ilmu \\ Penyakit Dalam Fakultas Kedokteran Universitas Padjadjaran-Rumah Sakit Dr. Hasan Sadikin \\ Bandung
}

\begin{abstract}
Abstrak
Gangguan ginjal akut (GgGA) merupakan penurunan fungsi ginjal secara mendadak yang ditandai dengan peningkatan kreatinin serum $\geq 0,3 \mathrm{mg} / \mathrm{dL}$ atau meningkat $>1,5$ kali dari kadar sebelumnya atau penurunan urine output (UO) $<0,5 \mathrm{~mL}$ per jam selama $>6$ jam. Sepsis merupakan penyebab tersering GgGA dengan angka kejadian berkisar $20-50 \%$ dan angka kematian mendekati $70 \%$. Kadar neutrophil gelatinase associated lipocalin (NGAL) urine penderita GgGA dapat meningkat secara cepat dan lebih awal dibandingkan dengan kadar kreatinin serum sehingga NGAL dapat dijadikan penanda diagnosis GgGA. Penelitian bertujuan mengetahui validitas NGAL urine sebagai penanda diagnosis GgGA pada penderita sepsis. Sebanyak 50 sampel urine diambil dari penderita sepsis di Unit Gawat Darurat (UGD), Intensive Care Unit (ICU), dan Medical Intermediate Care (MIC) di Rumah Sakit Dr. Hasan Sadikin Bandung selama Februari sampai Mei 2010 dan dilakukan pemeriksaan kadar NGAL urine dengan metode enzyme linked immunosorbent assay (ELISA). Data yang diperoleh dianalisis dengan uji nonparametrik Mann-Whitney, kurva receiver operating characteristic (ROC), dan uji validitas. Hasil penelitian didapatkan kadar NGAL urine penderita sepsis dengan GgGA lebih tinggi secara bermakna dibandingkan dengan penderita sepsis tanpa GgGA (3.380 ng/mL berbanding $116 \mathrm{ng} / \mathrm{mL}$; $\mathrm{p}<0,001)$. Pada cut-off point $107 \mathrm{ng} / \mathrm{mL}$, NGAL urine memiliki sensitivitas $100 \%$, spesifisitas $36 \%$, positive predictive value (PPV) $60,9 \%$, negative predictive value (NPV) $100 \%$, dan akurasi $68 \%$. Simpulan, kadar NGAL urine memiliki validitas yang baik dan dapat dijadikan sebagai penanda diagnosis terjadinya GgGA pada penderita sepsis. [MKB. 2012;44(2):121-6].
\end{abstract}

Kata kunci: Gangguan ginjal akut, kreatinin, neutrophil gelatinase associated lipocalin, penanda diagnosis, sepsis

\section{Validity Test of Neutrophil Gelatinase Associated Lipocalin as Diagnostic Marker forAcute Kidney Injury on Sepsis}

\begin{abstract}
Acute kidney injury (AKI) is an abrupt decrease of renal function which marked by increase of serum creatinine $\geq 0.3 \mathrm{mg} / \mathrm{dL}$ or $\geq 1.5$ times of previous level or decrease urine output $<0.5 \mathrm{~mL} /$ hour in $>6$ hours. Sepsis is the most common cause of AKI with incidence rate is about $20-50 \%$ and mortality nearly $70 \%$. Urine neutrophil gelatinaseassociated lipocalin (NGAL) level in AKI patients can increase quickly and earlier compared with serum creatinine and could be as a marker for AKI. The purpose of this study was to assess the validity of urine NGAL as diagnostic marker of AKI on sepsis patients. Subjects were 50 urine samples of sepsis patients from Emergency Department (ED), Intensive Care Unit (ICU) and Medical Intermediate Care (MIC) in Dr. Hasan Sadikin Hospital Bandung between February and May 2010 and were examined with enzyme linked immunosorbent assay (ELISA) method. Data analysis was performed by non parametric Mann-Whitney test, receiver operating characteristic (ROC) analysis and validity test. The results found that urine NGAL of AKI patients were significantly higher compared with non AKI patients $(3,380 \mathrm{ng} / \mathrm{mL}$ vs $116 \mathrm{ng} / \mathrm{mL}, \mathrm{p}<0.001)$. A cut-off point $>107 \mathrm{ng} / \mathrm{mL}$ for urine NGAL had a sensitivity of $100 \%$, specificity of $36 \%$, positive predictive value (PPV) of $60.9 \%$, negative predictive value (NPV) of $100 \%$ and accuracy of $68 \%$. In conclusions, urinary NGAL level has good validity and could be used as a screening test for AKI on sepsis patients. [MKB. 2012;44(2):121-6].
\end{abstract}

Key words: Acute kidney injury (AKI), creatinine, diagnostic marker, neutrophil gelatinase associated lipocalin, sepsis

Korespondensi: Hidayat, dr., Sp.PK, Laboratorium Patologi Klinik Rumah Sakit Dr. H. Abdul Moeloek Lampung, jalan Dr. Rivai 6 Bandar Lampung, mobile 081368250177,e-mail hidayatpatklin2007@yahoo.com 


\section{Pendahuluan}

Gangguan ginjal akut (GgGA) atau acute kidney injury (AKI) merupakan keadaan penurunan fungsi ginjal secara mendadak yang ditandai dengan peningkatan kadar kreatinin serum $\geq 0,3 \mathrm{mg} / \mathrm{dL}$ atau kenaikan kadar kreatinin serum $>1,5$ kali (lebih dari 50\%) bila dibandingkan dengan kadar sebelumnya atau penurunan urine output (UO) menjadi kurang dari $0,5 \mathrm{~mL}$ per jam selama lebih dari 6 jam. ${ }^{1,2}$ Kejadian GgGA banyak ditemukan di ruang Intensive Care Unit (ICU) dengan penyebab utama sepsis $(35,4 \%)$, obat-obatan $(35,4 \%)$, setelah tindakan bedah $(24,5 \%)$, dan toksik $(31,3 \%)$. Sepsis merupakan penyebab tersering komplikasi GgGA dengan angka kematian yang cukup tinggi. Sepsis dapat berkembang menjadi gagal organ multipel dan kematian. Angka kejadian GgGA pada penderita sepsis $20-50 \%$ dengan angka kematian mendekati $70 \%$. Oleh karena itu, diagnosis dini GgGA sangat diperlukan untuk menurunkan angka kematian GgGA yang tinggi, khususnya yang disebabkan oleh sepsis. ${ }^{3,4}$

Istilah acute kidney injury diperkenalkan oleh Acute Kidney Injury Network (AKIN) pada tahun 2005 untuk menggambarkan spektrum kerusakan ginjal secara akut dan selanjutnya dipakai istilah AKI, yaitu proses yang menyebabkan kerusakan ginjal dalam waktu 48 jam dan didefinisikan sebagai peningkatan kadar kreatinin serum $\geq 0,3 \mathrm{mg} / \mathrm{dL}$ (peningkatan 50\%) atau penurunan jumlah urine (keadaan oliguria dengan jumlah urine $<0,5 \mathrm{~mL} /$ $\mathrm{kg} / \mathrm{jam}$ lebih dari 6 jam). Kriteria diagnosis GgGA yang sekarang digunakan yaitu kriteria AKIN yang membagi tahapan GgGA menjadi tahap 1, 2, dan 3 sesuai dengan peningkatan kadar kreatinin serum dan jumlah UO., ${ }^{5,6}$

Penggunaan kreatinin serum sebagai salah satu kriteria diagnosis GgGA pada saat ini ternyata tidak sensitif untuk mendiagnosis GgGA secara dini. Kadar kreatinin dapat dipengaruhi oleh beberapa faktor di luar ginjal seperti berat badan, massa otot, ras, usia, jenis kelamin, obat-obatan, metabolisme otot, dan asupan protein. Kerusakan pada tubulus ginjal tidak selalu mengubah kadar kreatinin serum. Pada beberapa kasus dengan kerusakan tubulus yang berat, terdapat jeda waktu antara saat terjadinya kerusakan dan meningkatnya kadar kreatinin serum..$^{5,7,8}$

Neutrophil gelatinase associated lipocalin (NGAL) adalah protein-protein kecil termasuk keluarga protein lipocalin dengan berat molekul (BM) $21 \mathrm{kDa}$ dan terdapat dalam granula sekunder neutrofil yang akan dilepaskan jika terjadi aktivasi neutrofil. Protein ini berfungsi sebagai faktor pertumbuhan dan diferensiasi berbagai tipe sel seperti sel epitel tubulus renal dan bersifat bakteriostatik yang dapatmenghambat pertumbuhan bakteri. Selain terdapat dalam neutrofil dan sel epitel renal, NGAL dalam jumlah kecil juga terdapat pada sel epitel saluran pernapasan, saluran cerna, dan saluran kemih. Secara normal NGAL yang terdapat di dalam sirkulasi akan difiltrasi oleh glomerulus dan selanjutnya direabsorbsi oleh sel-sel epitel tubulus renal. Ekskresi NGAL dalam urine terjadi jika ada kerusakan sel epitel tubulus proksimal. $., 8,9$

Reaksi inflamasi yang terjadi pada penderita sepsis dapat menyebabkan kerusakan sel epitel tubulus proksimal akibat proses iskemik. Kerusakan sel epitel tubulus dapat meningkatkan kadar NGAL dalam urine akibat gangguan reabsorbsi oleh sel epitel tubulus proksimal. Kadar NGAL dalam urine semakin meningkat jika terjadi peningkatan pelepasan NGAL dari granula sekunder neutrofil yang teraktivasi sebagai respons terhadap reaksi inflamasi serta akibat sekresi oleh sel-sel epitel tubulus bagian distal pada segmen thick ascending limb of Henle's loop dan collecting duct yang merupakan mekanisme NGAL sebagai faktor pertumbuhan, proliferasi, dan diferensiasi sel epitel tubulus yang mengalami kerusakan. Peningkatan kadar NGAL urine lebih menunjukkan proses kerusakan ginjal dibandingkan dengan peningkatannya dalam sirkulasi. Peningkatan kadar NGAL dalam urine dapat terjadi 100 kali lebih cepat dibandingkan dengan kadar NGAL dalam sirkulasi dan telah terjadi pada saat awal terjadinya iskemik pada ginjal sehingga kadar NGAL urine dapat dijadikan penanda dini proses iskemik pada ginjal. ${ }^{10-13}$ Tujuan penelitian untuk mengetahui validitas pemeriksaan NGAL urine sebagai penanda diagnosis terjadinya GgGA pada penderita sepsis.

\section{Metode}

Subjek adalah penderita yang mengalami infeksi di Unit Gawat Darurat (UGD), Intensive Care Unit (ICU), dan Medical Intermediate Care (MIC) di Rumah Sakit Dr. Hasan Sadikin Bandung yang memenuhi kriteria inklusi. Kriteria inklusi penderita yang telah didiagnosis sepsis oleh klinisi berdasarkan kriteria The American College of Chest Physicians Society of Critical Care Medicine (ACCP/SCCP) 2001 serta menyatakan kesediaan ikut serta dalam penelitian dengan pernyataan tertulis (informed consent) yang diperoleh dari keluarga penderita.

Bahan pemeriksaan berupa urine sewaktu sebanyak $3 \mathrm{~mL}$ yang kemudian disentrifus pada kecepatan $3.000 \mathrm{rpm}$ selama 10 menit. Sebanyak $500 \mathrm{uL}$ supernatan dipisahkan dan disimpan dalam microtube pada suhu $-20{ }^{\circ} \mathrm{C}$ sampai memenuhi jumlah yang telah ditentukan dan diperiksa secara bersamaan. Metode pemeriksaan kadar NGAL urine dilakukan dengan cara enzyme linked immunosorbent assay (ELISA). 
Tabel 1 Karakteristik Subjek Penelitian

\begin{tabular}{|c|c|c|c|}
\hline \multirow[b]{2}{*}{ Karakteristik } & \multicolumn{2}{|c|}{ Kelompok } & \multirow[b]{2}{*}{$\mathbf{p}$} \\
\hline & $\underset{(n=25)}{\text { Sepsis dengan GgGA }}$ & $\underset{(n=25)}{\text { Sepsis tanpa GgGA }}$ & \\
\hline \multicolumn{4}{|l|}{ Jenis Kelamin } \\
\hline Laki-laki & 14 & 11 & 0,396 \\
\hline Perempuan & 11 & 14 & \\
\hline \multicolumn{4}{|l|}{ Usia (tahun) } \\
\hline Rata-rata (SD) & $48(14,9)$ & $39,2(16,2)$ & 0,051 \\
\hline Rentang & $23-71$ & $16-67$ & \\
\hline
\end{tabular}

Keterangan: Shapiro Wilks=distribusi normal, uji t $=1,998$; uji chi-kuadrat $\mathrm{X}^{2}=0,720$

Pengambilan bahan pemeriksaan dilakukan di UGD, ICU, dan MIC secara sampling from consecutive admissions. Pemeriksaan kadar NGAL urine dilakukan di Subbagian Imunologi Klinik Laboratorium Patologi Klinik RSHS Bandung. Penelitian ini dimulai dari Juni 2009 sampai Juni 2010. Pengumpulan bahan pemeriksaan dilakukan dari Februari sampai Mei 2010.

Penelitian ini sebagai penelitian epidemiologi klinik dengan rancangan penelitian potong lintang. Ukuran sampel penelitian ditentukan dengan pendekatan statistik formula uji hipotesis dua ratarata didapatkan jumlah sampel minimal sebanyak 44 yang terdiri atas 22 subjek untuk masing-masing kelompok.

Analisis statistik menggunakan uji normalitas Saphiro-Wilk yang dapat menggambarkan distribusi karakteristik data penelitian. Analisis statistik terdiri atas uji nonparametrik Mann-Whitney untuk membandingkan kadar NGAL urine pada dua kelompok. Analisis nilai cut-off point kadar NGAL urine dengan receiver operating characteristics (ROC) dan uji validitas pemeriksaan NGAL urine yang memuat nilai-nilai sensitivitas, spesifisitas, nilai duga positif, nilai duga negatif, dan akurasi.

\section{Hasil}

Selama kurun waktu penelitian diperoleh 50 subjek dengan diagnosis sepsis yang terdiri atas 25 subjek penderita sepsis dengan GgGA dan 25 subjek tanpa GgGA. Subjek penelitian berusia 16-71 tahun dengan rentang usia 23-71 tahun pada kelompok sepsis dengan GgGA dan 16-67 tahun pada kelompok sepsis tanpa GgGA. Usia rata-rata penderita sepsis dengan GgGA adalah 48 tahun (Tabel 1).

Berdasarkan hasil uji nonparametrik MannWhitney terdapat perbedaan bermakna antara kadar NGAL urine penderita sepsis dengan GgGA dan penderita sepsis tanpa $\mathrm{GgGA}$ (3.380 $\mathrm{ng} / \mathrm{mL}$ dengan $116 \mathrm{ng} / \mathrm{mL} ; \mathrm{p}<0,001$ ) (Tabel 2).

Analisis kurva ROC dengan area under curve (AUC) 0,87 didapatkan nilai cut-off point kadar NGAL urine.

Terlihat kadar NGAL urine pada beberapa nilai cut-off point memiliki beberapa nilai sensitivitas dan spesifisitas (Gambar, Tabel 3).

Hasil uji validitas mendapatkan kadar NGAL urine dengan cut-off point $107 \mathrm{ng} / \mathrm{mL}$ memiliki sensitivitas sebesar $100 \%$, spesifisitas $36 \%$, positive predictive value (PPV) 60,9\%, negative predictive value (NPV)100\%, dan akurasi 68\%. Kadar NGAL urine pada cut-off point $595 \mathrm{ng} / \mathrm{mL}$ memiliki sensitivitas $72 \%$, spesifisitas $88 \%$, nilai duga positif $85,7 \%$; nilai duga negatif $75,8 \%$; dan akurasi $82 \%$.

\section{Pembahasan}

Pada penelitian ini tidak terdapat perbedaan bermakna angka kejadian GgGA berdasarkan jenis kelamin meskipun jumlah subjek laki-laki lebih banyak mengalami GgGA dibandingkan dengan subjek perempuan $(\mathrm{p}=0,396)$. Belum ada kepustakaan yang menjelaskan apakah kejadian GgGA pada penderita sepsis lebih sering terjadi pada laki-laki dibandingkan dengan perempuan. Hasil penelitian ini sama dengan beberapa penelitian

Tabel 2 NGAL Urine pada Penderita dengan GgGA dan tanpa GgGA

\begin{tabular}{|c|c|c|c|}
\hline \multirow[b]{2}{*}{ NGAL (ng/mL) } & \multicolumn{2}{|c|}{ Kelompok } & \multirow[b]{2}{*}{$\mathbf{p}$} \\
\hline & $\begin{array}{c}\text { Sepsis dengan GgGA } \\
(\mathrm{n}=25)\end{array}$ & $\begin{array}{c}\text { Sepsis tanpa GgGA } \\
(\mathrm{n}=25)\end{array}$ & \\
\hline Median & 3.380 & 116 & \multirow{2}{*}{$<0,001$} \\
\hline Rentang & $115-4.735$ & $17-4.675$ & \\
\hline
\end{tabular}




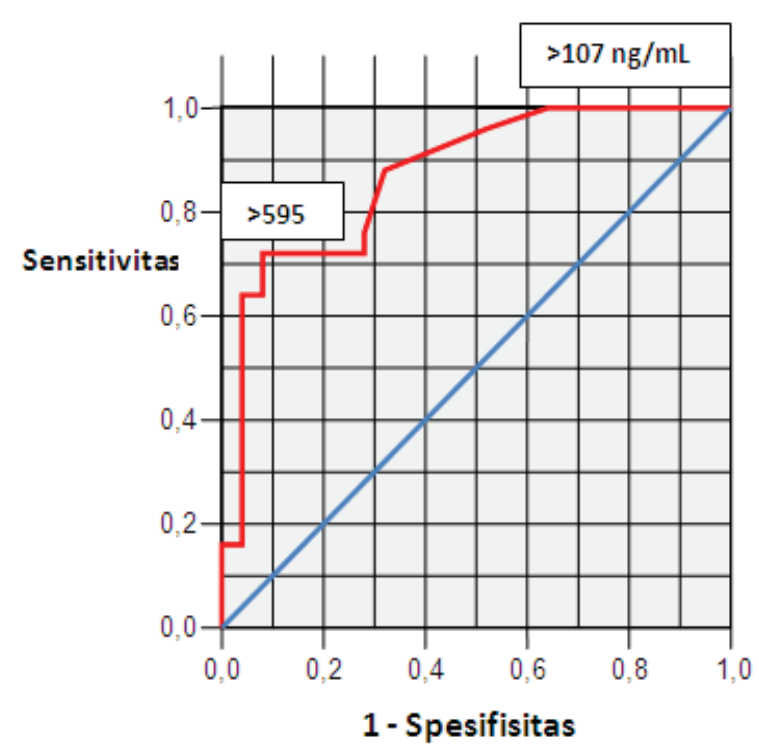

Gambar Kurva ROC untuk Menentukan Cutoff Point Kadar NGAL Urine

yang melaporkan bahwa angka kejadian GgGA pada penderita sepsis lebih banyak terjadi pada lakilaki. Hoste dkk. ${ }^{14}$ melaporkan $66,7 \%$ dari seluruh penderita sepsis di ICU yang menderita GgGA adalah laki-laki.

Usia merupakan salah satu faktor yang berpengaruh pada terjadinya GgGA pada penderita sepsis sehubungan dengan menurunnya fungsi sistem imun pada usia lanjut. Sepsis merupakan respons inflamasi sistemik tubuh terhadap masuknya mikroorganisme. Penurunan fungsi sistem imun dapat memperberat keadaan sepsis sehingga berakibat kegagalan fungsi organ seperti ginjal. Beberapa faktor lain dapat memengaruhi terjadinya GgGA seperti penyakit yang mendasari misalnya hipertensi, diabetes melitus, dan penurunan fungsi ginjal lebih sering terjadi pada usia lanjut. Pada penelitian ini faktor- faktor tersebut telah disingkirkan sebagai kriteria eksklusi. Hasil penelitian ini tidak didapatkan perbedaan bermakna berdasarkan usia antara subjek penelitian kelompok sepsis dengan GgGA dan tanpa GgGA ( $\mathrm{p}=0,051)$, meskipun pada kelompok sepsis dengan GgGA terjadi pada usia yang lebih tua. Hal ini dapat terjadi karena karakteristik subjek penelitian yang tidak homogen. Subjek penelitian adalah penderita sepsis yang terjadi karena infeksi pneumonia (38\%), setelah tindakan operasi (34\%), leptospira (4\%), kolesistitis (2\%), gastroenteritis $(2 \%)$, dan infeksi saluran kemih (ISK) $(2 \%)$. Berbagai kondisi klinis tersebut dapat terjadi pada semua tingkatan usia sehingga hasil penelitian tidak menunjukkan perbedaan bermakna berdasarkan usia. Hasil penelitian mempunyai kesamaan dengan beberapa penelitian lain seperti Hoste dkk. ${ }^{14}$ yang mendapatkan angka kejadian GgGA penderita sepsis pada usia 62 tahun dengan rentang usia antara 48 sampai 69,5 tahun.

Hasil uji normalitas menggunakan ShapiroWilk menunjukkan bahwa variabel kadar NGAL urine berdistribusi tidak normal dengan nilai $p<0,05$ sehingga data dianalisis dengan menggunakan uji nonparametrik yaitu Mann-Whitney.

Kadar NGAL urine penderita sepsis dengan GgGA berbeda secara bermakna dibandingkan dengan penderita sepsis tanpa GgGA $(3.380 \mathrm{ng} / \mathrm{mL}$ berbanding $116 \mathrm{ng} / \mathrm{mL} ; \mathrm{p}<0,001)$. Hal ini sesuai dengan kepustakaan yang menyatakan bahwa kadar NGAL urine pada penderita GgGA akan meningkat akibat kerusakan sel tubulus proksimal. ${ }^{6,89}$ Sepsis merupakan keadaan gangguan perfusi pada ginjal yang dapat menyebabkan iskemik dan kerusakan sel epitel tubulus proksimal ginjal. ${ }^{10,12}$ Pada GgGA didapatkan kadar NGAL urine meningkat lebih nyata dibandingkan dengan kadar NGAL serum. ${ }^{11,12}$ Hal ini terjadi akibat gangguan reabsorbsi NGAL oleh sel epitel tubulus proksimal, peningkatan sekresi oleh neutrofil yang teraktivasi, dan sekresi oleh sel epitel tubulus bagian distal. ${ }^{10,13}$ Sekresi

Tabel 3 Nilai Sensitivitas, Spesifisitas, PPV, NPV, dan Akurasi Pemeriksaan NGAL Urine pada Beberapa Cut-off Point

\begin{tabular}{lccccc}
\hline $\begin{array}{c}\text { Cut-off NGAL } \\
\text { (ng/mL) }\end{array}$ & $\begin{array}{c}\text { Sensitivitas } \\
(\mathbf{\%})\end{array}$ & $\begin{array}{c}\text { Spesifisitas } \\
(\mathbf{\%})\end{array}$ & $\begin{array}{c}\text { PPV } \\
(\mathbf{\%})\end{array}$ & $\begin{array}{c}\text { NPV } \\
(\mathbf{\%})\end{array}$ & $\begin{array}{c}\text { Akurasi } \\
(\mathbf{\%})\end{array}$ \\
\hline$>107$ & 100 & 36 & 60,9 & 100 & 68 \\
$>115,5$ & 96 & 48 & 64,8 & 92,3 & 72 \\
$>116,5$ & 88 & 64 & 73,4 & 85 & 76 \\
$>193,5$ & 76 & 72 & 73 & 75 & 74 \\
$>290$ & 72 & 72 & 72 & 72 & 72 \\
$>330$ & 72 & 76 & 75 & 73 & 74 \\
$>370$ & 72 & 80 & 78,2 & 74 & 76 \\
$>467,5$ & 72 & 84 & 81,8 & 75 & 80 \\
$>595$ & 72 & 88 & 85,7 & 75,8 & 82 \\
\hline
\end{tabular}

Keterangan: $\mathrm{PPV}=$ positive predictive value, $\mathrm{NPV}=$ negative predictive value 
NGAL oleh sel epitel tubulus pada segmen thick ascending limb of Henles's loop dan collecting duct terjadi mekanisme NGAL sebagai faktor pertumbuhan untuk proliferasi dan diferensiansi sel epitel tubulus proksimal. ${ }^{11-13}$ Hasil penelitian ini sesuai dengan penelitian Bangert dkk. ${ }^{15}$ yang mendapatkan bahwa kadar NGAL urine penderita sepsis dengan GgGA yang dirawat di ruang rawat intensif lebih tinggi secara bermakna dibandingkan dengan penderita tanpa GgGA (2693 ng/mL dengan $53 \mathrm{ng} / \mathrm{mL}$ ). Bagshaw dkk. ${ }^{16}$ juga mendapatkan kadar NGAL urine penderita GgGA akibat sepsis lebih tinggi bermakna dibandingkan dengan penderita sepsis tanpa GgGA (204 ng/mL berbanding $39 \mathrm{ng} /$ $\mathrm{mL}$ ).

Hasil penelitian ini menunjukkan rentang pengukuran kadar NGAL sangat besar, terutama pada kelompok sepsis tanpa GgGA $(17 \mathrm{ng} / \mathrm{mL}$ $-4.675 \mathrm{ng} / \mathrm{mL}$ ). Hal ini dapat disebabkan pada beberapa subjek penelitian penetapan kriteria sepsis menggunakan kriteria systemic inflammatory response syndrome (SIRS) yang merupakan tingkatan paling ringan dari tahapan sepsis. Pada tahapan ini belum terjadi kerusakan lebih lanjut pada sel tubulus ginjal jika dibandingkan dengan tingkatan sepsis yang lebih berat. Manifestasi SIRS dapat terjadi pada penderita sebagai komplikasi tindakan bedah. Pada penelitian ini sebanyak 20\% subjek penelitian dengan kadar NGAL urine yang rendah adalah penderita sepsis yang terjadi setelah tindakan bedah. ${ }^{11,12}$

Hasil analisis dengan kurva ROC terlihat beberapa nilai cut-off point kadar NGAL urine dengan nilai sensitivitas dan spesifisitas masingmasing (Tabel 3). Nilai sensitivitas tertinggi terdapat pada nilai cut-off point kadar NGAL urine $>107 \mathrm{ng} / \mathrm{mL}$ dan nilai spesifisitas tertinggi pada nilai cut-off point kadar NGAL urine $>595 \mathrm{ng} / \mathrm{mL}$. Penggunaan kadar NGAL urine sebagai uji skrining untuk mendeteksi GgGA pada penderita sepsis dapat menggunakan cut-off point kadar NGAL urine $>107 \mathrm{ng} / \mathrm{mL}$ dengan nilai sensitivitas $100 \%$, spesifisitas $36 \%$, nilai duga positif $60,9 \%$, nilai duga negatif $100 \%$, dan akurasi $68 \%$. Pada penelitian ini dengan cut-off point kadar NGAL urine $>107$ $\mathrm{ng} / \mathrm{mL}$ menunjukkan pada 16 subjek penderita sepsis tanpa GgGA yang didiagnosis berdasarkan kriteria klinis dengan menggunakan kadar kreatinin serum sebagai salah satu kriteria AKIN memiliki kadar NGAL urine di atas nilai cut-off point. Pada cut-off point tersebut, kadar NGAL urine dapat memprediksi terjadinya GgGA pada 16 subjek penelitian yang memperlihatkan kadar NGAL urine ternyata meningkat lebih awal dibandingkan dengan peningkatan kadar kreatinin serum. Hal ini sesuai dengan kepustakaan yang menyatakan bahwa kadar kreatinin serum saat ini tidak lagi sensitif dalam menegakkan diagnosis GgGA.
Peningkatan kreatinin tidak menggambarkan proses kerusakan yang sebenarnya pada ginjal. Beberapa hasil penelitian yang membandingkan parameter kreatinin serum dengan kadar NGAL urine pada penderita GgGA dilaporkan bahwa peningkatan kadar NGAL urine terjadi lebih awal dibandingkan dengan peningkatan kadar kreatinin serum. ${ }^{13}$

Pada cut-off point kadar NGAL urine $>595$ $\mathrm{ng} / \mathrm{mL}$ memiliki nilai sensitivitas $72 \%$, spesifisitas $88 \%$, nilai duga positif $85,7 \%$, nilai duga negatif $75,8 \%$, dan nilai akurasi $80 \%$. Perbedaan nilai spesifisitas yang lebih tinggi dibandingkan dengan nilai sensitivitasnya, pemeriksaan NGAL urine ideal digunakan sebagai pemeriksaan konfirmasi diagnostik untuk membuktikan telah terjadi GgGA. Pada cut-off point kadar NGAL urine $>595 \mathrm{ng} / \mathrm{mL}$ dapat mengonfirmasi GgGA pada penderita yang telah terdiagnosis $\mathrm{GgGA}$ dengan kriteria klinis.

Hasil penelitian ini jika dibandingkan dengan hasil penelitian lain, beberapa di antaranya memiliki kesamaan dalam hal nilai sensitivitas yang lebih tinggi dibandingkan dengan spesifisitas. Trachtman dkk. ${ }^{17}$ mendapatkan hasil pemeriksaan kadar NGAL urine pada cut-off point $>200 \mathrm{ng} / \mathrm{mL}$ dapat memprediksi GgGA pada anak yang menderita diare yang berhubungan dengan hemolytic uremia syndrome (HUS). Makris dkk. ${ }^{18}$ mendapatkan hasil pemeriksaan kadar NGAL urine pada cut-off point $>25 \mathrm{ng} / \mathrm{mL}$ memiliki sensitivitas dan spesifisitas tinggi untuk memprediksi GgGA pada penderita yang dirawat di ICU akibat trauma multipel. Yilma dkk. ${ }^{19}$ mendapatkan hasil pemeriksaan kadar NGAL urine pada cut-off point $>20 \mathrm{ng} / \mathrm{mL}$ dapat memprediksi GgGA pada anak akibat infeksi saluran kemih. Perbedaan nilai cut-off point pada penelitian-penelitian tersebut dapat disebabkan karena perbedaan karakteristik subjek penelitian yang digunakan. Secara teori, GgGA merupakan kondisi multifaktorial dari yang ringan sampai berat bergantung pada kondisi yang mendasari terjadinya. Penetapan nilai cut-off point tidak dapat disamakan pada berbagai kondisi tersebut karena mekanisme yang mendasari terjadinya GgGA juga berbeda. ${ }^{20}$

Pemeriksaan kadar NGAL urine dapat dipakai sebagai penanda diagnosis GgGA pada penderita sepsis dengan melihat nilai sensitivitas pemeriksaan kadar NGAL urine. Pada cut-off kadar NGAL urine $>107 \mathrm{ng} / \mathrm{mL}$ memiliki nilai sensitivitas yang tinggi $(100 \%)$ sehingga ideal sebagai pemeriksaan skrining terjadinya GgGA.

Simpulan, kadar NGAL urine memiliki validitas yang baik dan dapat dijadikan penanda dugaan GgGA pada penderita sepsis.

\section{Daftar Pustaka}

1. Molitoris BA, Levin A, Warnock DG. Acute 
kidney injury network. Improving outcomes from acute kidney injury. J Am Soc Nephrol. 2007;18:1992-4.

2. Mehta RL, Kellum JA, Shah SV. Acute kidney injury metwork: report of an initiative to improve outcomes in acute kidney injury. Crit Care. 2007;11:31-5.

3. Liano F, Pascual J. Epidemiologi of acute renal failure: a prospective, multicenter, community based study. Kidney Int. 1996;50:811-8.

4. Ronco C, Bellomo R, Brendolan A. Sepsis, kidney and multiple organ dysfunction. Contributions to Nephrol. 2004;144:12-8.

5. Ronco C, Bellomo K, Kellum JA. Acute kidney injury. Contributions to Nephrol. 2007;156:328.

6. Han WK. Biomarker for early detection of acute kidney injury. Nephrol Rounds. 2008;1:661-91.

7. Hoste EAJ, Clemont G, Kersten A, Venkatraman $\mathrm{R}$, Angus DC, Bacquer DD, dkk. RIFLE criteria for acute kidney injury are associated with hospital mortality in critically ill patients: a cohort analysis. Crit Care. 2006;10:73.

8. Coca SG, Parikh CR. Urinary biomarkers for acute kidney injury: perspectives on translation. Clin J Am Soc Nephrol. 2008;3:481-90.

9. Tang Z, Wu X, Ovcharenko D, Zhu J, Chen CS, Kehrer JP. Neutrophil gelatinase associated lipocalin as a survival factor. Biochem J. 2005;391:441-8.

10. Schrier RW, Wang W. Acute renal failure and sepsis. N Eng J Med. 2004;351:159-69.

11. Devarajan P. Neutrophil gelatinase associated lipocalin an emerging troponin for kidney injury. Nephrol Dial Transplant. 2008;23(12):373743.

12. Mishra J, Ma Q, Prada A, Mitsnefes M, Zahedi $\mathrm{K}$, Yang J, dkk. Identification of neutrophil gelatinase associated lipocalin as a novel early urinary biomarker for ischemic renal injury. J Am Soc Nephrol. 2003;14:2534-43.
13. Mori K, Lee HT, Rapoport D, Drexler IR, Footer K, Yang J, dkk. Endocytic delivery of lipocalin siderophore iron complex rescues the kidney from ischemia reperfusion injury. J Clin Investigation. 2005;3:610-20.

14. Hoste EAJ, Lameire NH, Vanholder RC, Benoit DD, Decruyenaere JMA, Colardyn FA. Acute renal failure in patients with sepsis in a surgical ICU: predictive factors, incidence, comorbidity, and outcome. J Am Soc Nephrol. 2003;14:1022-30.

15. Bangert K, Heslet L, Ghiglione M, Utthenthal LO. Neutrophil gelatinase associated lipocalin is significantly increased in urine and plasma in acute renal failure. Intensive Care Med. 2006;32(Suppl 1):S10.

16. Bagshaw SM, Bennet M, Haase M, Haase Fielitz A, Egi M. Plasma and urine neutrophil gelatinase associated lipocalin in septic versus non septic acute kidney injury in critical illness. Intensive Care Med. 2010;36:452-61.

17. Trachtman H, Christen E, Cnaan A, Patrick J, Mai V, Mishra J, dkk. Urinary neutrophil gelatinase associated lipocalin in D + HUS: a novel marker of renal injury. Pediatr Nephrol. 2006;21:989-94.

18. Makris K, Markov N, Evodia E, Dimopoulo E, Drakopoulous L, Ntetsika K. Urinary neutrophil gelatinase associated lipocalin as an early marker of acute kidney injury in critically ill multiple trauma patients. Clin Chem Lab Med. 2009;47:79-82.

19. Yilma A, Sevketoglu E, Gedikbasi A, Karyogor S, Kiyak A, Mulazimoglu M, dkk. Early prediction of urinary tract infection with urinary neutrophil gelatinase associated lipocalin. Pediatr Nephrol. 2009;24:2387-93.

20. Parikh CR, Garg AX. Testing new biomarkers for acute kidney injury: association, prediction and intervention. Am J Kidney Dis. 2009;54:987-9. 